\title{
Impact of SMS-Based Agricultural Information on Indian Farmers
}

\author{
Marcel Fafchamps and Bart Minten
}

\begin{abstract}
This study estimates the benefits that Indian farmers derive from market and weather information delivered to their mobile phones by a commercial service called Reuters Market Light (RML). We conduct a controlled randomized experiment in 100 villages of Maharashtra. Treated farmers associate RML information with a number of decisions they have made, and we find some evidence that treatment affected spatial arbitrage and crop grading. But the magnitude of these effects is small. We find no statistically significant average effect of treatment on the price received by farmers, crop value-added, crop losses resulting from rainstorms, or the likelihood of changing crop varieties and cultivation practices. Although disappointing, these results are in line with the market take-up rate of the RML service in the study districts, which shows small numbers of clients in aggregate and a relative stagnation in take-up over the study period. JEL codes: O13, Q11, Q13.
\end{abstract}

The purpose of this study is to ascertain whether agricultural information distributed through mobile phones generates economic benefits to farmers. We implement a randomized controlled trial of a commercial service entitled Reuters Market Light (RML) offered by the largest and best-established private provider of agricultural price information in India at the time of the experiment. Operating in Maharashtra and other Indian states, RML distributes price, weather, and crop advisory information through SMS messages. We offered a one-year free subscription to RML to a random sample of farmers to test whether they obtain higher prices for their agricultural output.

Marcel Fafchamps is a professor at Oxford University, United Kingdom; his email address is marcel. fafchamps@economics.ox.ac.uk. Bart Minten is a senior research fellow at the International Food Policy Research Institute; his email address is b.minten@cgiar.org. The authors thank Dilip Mookherjee, Shawn Cole, Sujata Visaria, three anonymous referees, and the editor for discussion and suggestions. This research would not have been possible without the full cooperation of Thomson Reuters India. The authors are particularly grateful to Raj Bhandari, Rantej Singh, Ranjit Pawar, and Amit Mehra for their constant support, to Alastair Sussock, Sudhansu Behera, Gaurav Puntambekar, and Paresh Kumar for their research assistance in the field, and to Grahame Dixie for his encouragements, suggestions, and comments. Funding for this research was provided by the World Bank and Thomson Reuters. A supplemental appendix to this article is available at http://wber.oxfordjournals.org/.

THE WORLD BANK ECONOMIC REVIEW, VOL. 26, NO. 3, pp. 383-414

doi:10.1093/wber/lhr056

Advance Access Publication February 27, 2012

(C) The Author 2012. Published by Oxford University Press on behalf of the International Bank for Reconstruction and Development / THE WORLD BANK. All rights reserved. For permissions, please e-mail: journals.permissions@oup.com 
We also investigate the channels through which the price improvement comes: better arbitrage across space and time; ability to bargain with traders; and increased awareness about quality premium leading to better agricultural practices and postharvest handling. We present simple models of the first two channels. Both models make testable predictions about farmer behavior in response to market price information. We test for the presence of these necessary channels. Given that RML circulates weather and crop advisory information, we also examine whether profits increase thanks to better crop management, reduced losses, or improved quality.

There is a large interest and takeoff of similar private and public programs in India (Mittal, Gandhi, and Tripathi 2010) and elsewhere (Staatz, Kizito, Weber, and Dembélé 2011), indicating that it is important to understand the impact of these interventions. ${ }^{1}$ Based on this, we expected to find a large and significant effect of RML on treated farmers.

These expectations find less support than anticipated in our results. Many treated farmers state that they use the RML information, and they are less likely to sell at the farm-gate and more likely to change the market at which they sell their output. These findings are consistent with the idea that treated farmers seek arbitrage gains from RML information. We do not, however, find any significant difference in price between beneficiaries of the RML service and non-beneficiaries. This result is robust to the choice of estimator and methodology. There is some evidence of heterogeneous effects: Treated farmers who are young-and presumably less experienced-receive a higher price in some regressions, but the effect is not particularly robust.

Why we do not find a stronger effect of RML on the prices received by farmers is unclear. Over the study period there were important changes in prices, which are part of a general phenomenon of food price inflation in India (see, for example, World Bank 2010). Although rapidly changing prices should in principle make market information more valuable, it is conceivable that the magnitude of the change blunted our capacity to identify a significant price difference, given how variable prices are. Point estimates of the treatment effect on price received are, however, extremely small and sometimes negative. We also find no significant evidence of an effect on transaction costs, net price, revenues, and value-added.

In other channels by which RML may affect farmers, we find a statistically significant but small increase of the likelihood of grading or sorting the crop. This is especially true for younger farmers, possibly explaining why they achieve better prices. RML shows prices by grade to farmers and might have helped to inform them about the benefit from grading. With respect to other

1. In India, apart from RML, other initiatives include the Indian Farmers Fertilisers Cooperative Limited (IFFCO) Kisan Sanchar Limited (IKSL), a partnership between Bharti Airtel and IFFCO, as well as the fisher friend program by Qualcomm and Tata Teleservices, in partnership with the MS Swaminathan Research Foundation. In western Africa, Manobi and Esoko, private ICT providers, have developed a number of SMS applications to facilitate agricultural marketing there. 
RML information, we find no systematic change in behavior due to weather information and no change on the crop varieties grown or cultivation practices. Farmers who changed variety or cultivation practice do, however, list RML as a significant source of information in their decision. To summarize, RML benefits appear minimal for most farmers, even though RML is associated with significant changes in where farmers sell their crops. There is some evidence that young farmers benefit more from the service, but the effect is not robust.

\section{Description of the Intervention and Experimental Design}

The Indian branch of Thomson-Reuters distributes agricultural information to farmers through a service called Reuters Market Light (RML). Subscribers are provided with SMS messages in English or the local language of their choicein total 75 to 100 SMS per month. Subscribers are offered a menu of three agricultural markets and three crops to choose from. This menu is based on market research of farmers' information needs and a pilot marketing program carried out in 2006-07. Prior to the experiment, Reuters gathered encouraging anecdotal information from farmers regarding the usefulness of RML.

At the time of the experiment, Reuters had about 25,000 RML subscribers in Maharashtra. The RML content included market information, weather forecast, crop advisory tips, and commodity news. At the time of the study the price for the service was about $\$ 1.50$ per month. Thomson Reuters is a transnational corporation specializing in market information services, its core business. The corporation has a long experience collecting and selling market information and a reputation for accuracy. Although Thomson Reuters did not disclose how it obtains market price information, we have no reason to suspect that the provided information is inaccurate. Doubts about data accuracy would be detrimental to the firm's reputation and would hurt its effort to market RML across India.

A randomized controlled trial (RCT) was organized by the authors to test the effect of RML on the price received by farmers. The RCT was conducted in close collaboration with Thomson Reuters. Five crops were selected as the focus for the study: tomatoes, pomegranates, onions, wheat, and soybeans. In Maharashtra these crops are all grown by smallholders primarily for sale. Whereas wheat and soybeans are storable, the other three crops are not and should be subject to greater price uncertainty due to short-term fluctuations in supply and demand (Aker and Fafchamps 2011). We expect market information to be more relevant for perishable crops. Soybeans have long been grown commercially in Maharashtra, but tomatoes, onions, and pomegranates are more recent commercial crops. We expect farmers to be more knowledgeable about well-established market crops-such as wheat and soybeans-than about crops whose commercial exploitation is more recent-such as tomatoes, onions, and pomegranates. Finally, pomegranate is a tree crop that is sensitive to unusual weather and requires pesticide application. We expect the benefit 
from weather information and crop advisories to be more beneficial to pomegranate farmers.

For each of the five crops, we selected one district where the crop is widely grown by small farmers for sale: Pune for tomatoes, Nashik for pomegranates, Ahmadnagar for onions, Dhule for wheat, and Latur for soya. All five districts are located in the central region of Maharashtra; we avoided the eastern part of the state where sporadic Maoist activity has been reported, and the western part of the state which is less suitable for commercial agriculture.

A total of 100 villages were selected for the study, 20 in each of the 5 districts. The villages were chosen in consultation with Thomson Reuters to ensure they were located in areas not previously targeted by RML marketing campaigns. Ten farmers were then selected from each village, yielding a total intended sample size of 1,000 farmers. ${ }^{2}$

Two treatment regimes were implemented. In the first regime-treatment 1-all 10 farmers in the selected village were offered free RML. In the second regime-treatment 2-three farmers randomly selected among the village sample were offered RML. The purpose of treatment 2 is to test whether the treatment of some farmers benefit others as well. Farmers who are not signed up are used to evaluate the externalities generated if farmers share RML information.

Bruhn and McKenzie (2009) show that, in RCTs, stratification improves efficiency. Randomization of treatment across villages was thus implemented by constructing, in each district, triplets of villages that are as similar as possible along a number of dimensions that are likely to affect the impact of the treatment. ${ }^{3}$ A description of the process is provided in the supplemental appendix 1 , available at http://wber.oxfordjournals.org/.

We also offered RML to randomly selected extension agents covering half of the treatment 1 and treatment 2 villages. In principle, extension agents could disseminate the relevant information they receive, making it unnecessary to distribute it to individual farmers. Whether they do so in practice is unclear, given that extension agents visit villages infrequently.

The object of the RCT is to estimate the impact of RML on farmers who voluntarily sign up for the service because they benefit from it. In villages targeted by RML, only a small proportion of farmers sign up. They tend to be larger farmers with a strong commercial orientation in RML crops. There is no

2. This sample size was determined as follows. The primary channel through which we expect SMS information to affect welfare is the price received by producers. We therefore want a sample size large enough to test whether SMS information raises the price received by farmers. Goyal (2010) presents results suggesting that price information raises the price received by Indian farmers by 1.6 percent on average. Based on this estimate and its standard error, a simple power calculation indicates that a total sample size of 500 farmers should be sufficient to identify a 1.6 percent effect at a 5 percent significance level. To protect against loss of power due to clustering, we double the sample size to 1,000 . We did not have sufficient information to do a proper correction of our power calculations for clustering.

3. More precisely, 6 triplets and one pair. 
point estimating the effect of RML on people unlikely to benefit from it. For this reason, participants are limited to farmers growing the district-specific selected crop for sale. These farmers have a large enough marketed surplus to amortize the cost of information gathering and enough experience with the crop to benefit from agricultural information. It remains that the farmers to whom we offered RML did not express an initial interest in it and may have dismissed the usefulness of something they did not pay for.

Since a mobile phone is required to receive RML messages, we limit participants to farmers with a mobile phone at the time of the baseline survey. We omit farmers who already were RML customers prior to baseline because they could not be used for impact analysis. Because we carefully avoided areas in which RML had already been actively promoted, few farmers were eliminated due to this condition. Further details on the sample and survey design are found in supplemental appendix 2 .

\section{Conceptual Framework}

Our primary objective is to test whether farmers benefit from the SMS-based market information and, if so, how. Information gathered by Thomson Reuters and conversations with farmers and RML customers in villages of Maharashtra suggest that farmers benefit in several ways. According to this information, timely access to market price information at harvest helps farmers decide where to sell, as in Jensen (2007). It also enables them to negotiate a better price with traders.

To illustrate how informed farmers may obtain a higher price through better arbitrage, consider a farmer selecting where to sell his output. There are two possible markets, $i$ and $j$, with transport costs $\tau_{i}$ and $\tau_{j}$. We assume $\tau_{j}>\tau_{i}$, that is, market $j$ is the more distant market. To focus on arbitrage, we assume that the distribution of producer prices $F(p)$ is the same in both markets. In particular, $E\left[p_{i}\right]=E\left[p_{j}\right]=\mu$. Given this, it is optimal for an uninformed farmer to always ship his output to market $i$ since $E U\left(p_{i}-\tau_{j}\right)<E U\left(p_{j}-\tau_{i}\right)$ for any utility function $\mathrm{U}(.)^{4}{ }^{4}$ The average price received by farmers is thus $\mu$. A relevant special case is when $i$ is selling at the farm-gate to an itinerant buyer and $j$ is selling at the nearest market. In that case the farmer incurs no transaction cost, receives price $p_{i}$, and does not learn the market price $p_{j}$.

Now suppose that the farmer is given information on prices in $i$ and $j$. Shipping to $i$ remains optimal if $p_{i}-\tau_{i} \geq p_{j}-\tau_{j}$; otherwise, the farmer ships to $j$. The average farmer price now is:

$$
\begin{aligned}
& E\left[p_{i} \mid p_{i}-\tau_{i} \geq p_{j}-\tau_{j}\right] \operatorname{Pr}\left(p_{i}-\tau_{i} \geq p_{j}-\tau_{j}\right) \\
& \quad+E\left[p_{j} \mid p_{i}-\tau_{i}<p_{j}-\tau_{j}\right] \operatorname{Pr}\left(p_{i}-\tau_{i}<p_{j}-\tau_{j}\right) \geq \mu
\end{aligned}
$$

4. Since $p-\tau_{i}>p-\tau_{j}$ point wise. There is no role for risk aversion in this model. 
This equation holds with equality only if $p_{i}$ is always larger than $p_{j}-\left(\tau_{j}-\right.$ $\left.\tau_{i}\right)$. This arises only if $\tau_{j}-\tau_{i}$ is large relative to the variance of prices or if prices in the two markets are strongly correlated. It follows that if price information allows farmers to arbitrage better across markets, the average farmer price should rise and we should observe farmers now selling in different, more distant markets. ${ }^{5}$ In the case of farm-gate sales, obtaining information about $p_{j}$ induces farmers to sell at the market if $p_{j}>p_{i}+\tau_{j}$ where $p_{i}$ is the price offered by itinerant buyers.

There remains the issue of why $p_{i} \neq p_{j}$ in the first place: If farmers can arbitrage, so can traders. Let $\theta$ be the trader shipment cost between $i$ and $j$. With perfect information, trader arbitrage yields:

$$
p_{j}+\theta \leq p_{i} \leq p_{j}-\theta
$$

and thus $\left|p_{i}-p_{j}\right| \leq \theta$. Farmer arbitrage therefore arises whenever $\tau_{j}-\tau_{i}<$ $\theta$, that is, when farmers have access to cheap transport to markets. ${ }^{6}$ However, if traders have a comparative advantage in transport-for instance, because they ship larger quantities and benefit from returns to scale-then it is possible that $\tau_{j}-\tau_{i}>\theta$ for most if not all farmers. In this case, $\operatorname{Pr}\left(p_{i}-\tau_{i}<p_{j}-\tau_{j}\right)=$ 0 , which implies that farmers always sell at the closest market or location $i$, and the average farmer price is $\mu$, as in the case without information.

Even when price information does not trigger farmer arbitrage, it may facilitate arbitrage by traders, thereby ensuring that $\left|p_{i}-p_{j}\right| \leq \theta$ (Aker and Fafchamps 2011). If farmers are risk averse, they would benefit from the reduction in the variance of prices, ${ }^{7}$ irrespective of whether they receive market information $p_{i}$ and $p_{j}$ or not prior to deciding where to ship their output.

The second way farmers can benefit from price information is when they sell to traders who are better informed about market prices-for example, when selling at the farm-gate. To illustrate, consider price negotiation between an informed trader who knows the market price realization $p_{i}$, and an uninformed farmer who only knows the price distribution $F\left(p_{i}\right)$. To demonstrate how information can benefit the farmer, imagine that the farmer mimics an auction system and calls a decreasing sequence of selling prices until the trader accepts it. In a competitive market with many buyers-which makes collusion difficult-the selling price will be $p_{i}$. In a one-on-one negotiation, as would

5. A similar reasoning applies to intertemporal arbitrage: Uninformed farmers may prefer to sell immediately after harvest, whereas better informed farmers may choose to sell at a later date if the anticipated price is higher. Since RML does not disseminate information about future prices, however, we do not expect an intertemporal arbitrage effect, except perhaps in the immediate vicinity of harvest. Several of the studied crops are perishable; this further limits opportunities for intertemporal arbitrage.

6. For instance, if transport costs per kilometer are identical for farmers and traders, condition $\tau_{j}-$ $\tau_{i}<\theta$ holds generically on a plane, except when the farmer and the two markets are exactly in a straight line. With many farmers distributed randomly on the plane, this has Lebesgue measure zero.

7. Except when they consume much of their output, something that is ruled out here since the empirical analysis focuses on commercial crops 
take place at the farm-gate, the buyer correctly anticipates that the farmer will continue calling lower prices below $p_{i}$. He can thus wait for the farmer to reach his reservation price, which is the value of the farmer's next best alternative, namely, selling at the nearest market.

The expected payoff to an uninformed farmer of selling at the market is $E U\left(p_{i}-\tau_{i}\right)$. Let $\tilde{p}_{l} \equiv p_{i}-\tau_{i}$ be the market price net of transport cost, and let $\tilde{\mu} \equiv E\left[\tilde{p}_{i}\right]$. The farm-gate reservation price of a risk-averse farmer is the price $p_{i}^{r}=\tilde{\mu}-\pi$ that solves:

$$
U(\tilde{\mu}-\pi)=E U\left(\tilde{p}_{l}\right)
$$

Using a standard Arrow-Pratt Taylor expansion, we get:

$$
U(\tilde{\mu})-U^{\prime}(\tilde{\mu}) \pi \approx E\left[U(\tilde{\mu})+U^{\prime}(\tilde{\mu})\left(\tilde{\mu}-\tilde{p}_{l}\right)+\frac{1}{2} U^{\prime} \iota(\tilde{\mu})\left(\tilde{\mu}-\tilde{p}_{l}\right)^{2}\right]
$$

which we can solve for $\pi$ :

$$
\pi \approx-\frac{1}{2} \frac{U^{\prime \prime}(\tilde{\mu})}{U^{\prime}(\tilde{\mu})} \sigma^{2}=\frac{1}{2} R C V^{2}
$$

where $R$ is the farmer's coefficient of relative risk aversion, $\sigma^{2}$ is the variance of the market price, and $C V \equiv \sigma / \tilde{\mu}$ is the coefficient of variation of price. It follows that a buyer can always buy from an uninformed farmer at price $p_{i}^{r}=\tilde{\mu}-\pi$. Only if the realized market price $p_{i}<p_{i}^{r}$ is the farmer unable to find farm-gate buyers - in which case he must travel to the market and sell at $p_{i}<\tilde{\mu}+\tau_{i}-\pi$ but incur transport cost $\tau_{i}$. The average price received by an uninformed farmer is:

$$
\begin{aligned}
\left(\mu-\tau_{i}-\pi\right) \operatorname{Pr}\left(p_{i} \geq \mu-\tau_{i}-\pi\right)+ & E\left[p_{i} \mid p_{i}<\mu-\tau_{i}-\pi\right] \\
& \operatorname{Pr}\left(p_{i}<\mu-\tau_{i}-\pi\right) \leq \mu-\tau_{i}
\end{aligned}
$$

It follows that the larger $R$-and thus $\pi$-is, the lower the average farmer price is. If risk aversion is negatively correlated with wealth, the above predicts that poor uninformed farmers receive a lower average price than non-poor uninformed farmers. Similarly, the larger $C V$ is-for instance, because the farmer is inexperienced and unsure about the price distribution-the lower the average farm-gate price is.

Once we introduce price information, the farmer's farm-gate reservation price becomes $p_{i}-\tau_{i}$ and buyers are no longer able to exploit farmers' risk aversion to buy below the market price. The expected price received by farmers is $\mu-\tau_{i}$ if they sell at the farm-gate, or $\mu$ if they sell in the market. Hence, the average price received by informed farmers is unambiguously higher than that of uninformed farmers. The difference is largest when uninformed farmers 
often sell at the farm-gate. If farmers do not sell at the farm-gate at all, information has no effect on the average price farmers receive. ${ }^{8}$

The two models above do not exhaust the possible channels by which price information may affect farmer prices. In India one important possibility is excessive fees collected by commission agents (Minten, Vandeplas, and Swinnen 2012). However, since RML circulates no information about market fees, it is unclear why it should lead to their reduction.

Model predictions regarding prices can be summarized as follows. If price information enables farmers to arbitrage across markets, treated farmers should receive a higher price than control farmers, but only if treated farmers start selling in distant markets. Otherwise, we expect no difference between control and treated farmers. The introduction of RML, however, could reduce the variance of prices for everyone through trader arbitrage, as in Aker and Fafchamps (2011).

If price information helps farmers negotiate better prices with traders, treated farmers should receive a higher average price only if they were selling at the farm-gate prior to treatment. For these farmers, we expect a stronger treatment effect for poor and inexperienced farmers. For farmers who were selling primarily if not exclusively through wholesale markets, we expect no effect of the treatment on price. But treatment may nevertheless induce farmers to sell at the farm-gate for convenience reasons, or if traders have a comparative advantage in transporting produce from the farm-gate.

RML may benefit farmers in other ways, which we do not model since they are more straightforward. Better knowledge of quality-driven price differentials may induce farmers to upgrade output quality, for instance by grading or treating their crops. Weather information helps with farm operations. In particular, information about the probability of rainfall enables farmers to either delay (pesticide application) or speed up (harvest) certain farm operations. Information about air moisture is a good predictor of pest infestation and hence of the need to apply pesticide. Crop advisories assist farmers to choose a more appropriate technology (choice of variety, pesticide, and fertilizer).

\section{Testing Strategy}

We now describe how we test the above predictions. Since the data are balanced, we ascertain the effect of RML on outcome indicators by comparing control and treatment in the ex post survey. Formally, let $Y_{i}$ represent an

8. Uninformed farmers would benefit if they could commit to sell at the market. If such a commitment mechanism is unavailable, however, farmers can always be tempted to sell at the farm-gate if offered a price above their reservation price. Of course, a sophisticated but uninformed farmer should infer that if a trader is willing to buy from him at the farm-gate, the market price must be above his reservation price, in which case he should sell at the market. If farmers are sophisticated, we should therefore observe few if any farm-gate sales by uninformed farmers. In this case, providing market information to farmers should make farm-gate sales more common. 
outcome indicator-for example, price received-for farmer $i$. Let $W_{i}=1$ if farmer $i$ was offered a free subscription to the SMS-based market service, and $S_{i}=1$ if farmer $i$ signed up for the service. All treated farmers are in treated villages but the converse is not true: only some farmers in treatment 2 villages were offered RML. It is possible for treated farmers not to sign up for the service-that is, for $S_{i}=0$ even though $W_{i}=1$. Although control villages were not targeted by RML marketing campaigns, it is also possible for nontargeted farmers to independently sign up-that is, for $S_{i}=1$ even though $W_{i}=0$.

We are interested in estimating the direct effect of RML on customers, that is, those with $S_{i}=1$. Since $S_{i}$ is subject to self-selection and $W_{i}$ is not, we begin by reporting intent-to-treat estimates that compare control farmers to those who were offered the free subscription. The estimating equation is:

$$
Y_{i}=\theta+\beta W_{i}+e_{i}
$$

Next we investigate the effect of receiving the RML subscription. As we will see, the likelihood of signing up is much higher among farmers who received the offer of a free subscription. This means that $W_{i}$ satisfies the inclusion restriction and can be used as instrument for $S_{i}$. We thus estimate an instrumental variable (IV) model of the form:

$$
Y_{i}=\theta+\alpha S_{i}+e_{i}
$$

where $e_{i}$ is an error term possibly correlated with $S_{i}$ (self-selection effect) but uncorrelated, by design, with the instrument $W_{i}$.

Provided that there are no defiers, we can interpret IV estimates from equation (8) as local average treatment effects (LATE). Assuming no defiers means that farmers who did not sign up for RML even though they were offered a free subscription would not have signed up for it if they had not been offered a free service. In our setup, this assumption is unproblematic. We can therefore interpret $\alpha$ in equation (8) as the effect of RML for a farmer who would be induced to sign up if offered the service for free. This is the IV-LATE approach.

Equation (7) can be generalized to investigate heterogeneous effects. Let $X_{i}$ be a vector of characteristics of farmer $i$ thought to influence the effect of the treatment. We expect larger RML benefits for commercial farmers who emphasise crops for which RML information is useful. We also expect less experienced farmers to more benefit. The estimated model becomes:

$$
Y_{i t}=\theta+\alpha W_{i}+\gamma X_{i}+\eta W_{i}\left(X_{i}-\bar{X}\right)+e_{i}
$$

where $\bar{X}$ denotes the sample mean of $X_{i}$. The average treatment effect is given by $\alpha$, whereas the heterogeneous effects of treatment on a farmer with characteristic $X_{i}$ is $\alpha+\eta\left(X_{i}-\bar{X}\right)$. 
When interpreting models (7), (8), and (9), one must remember that identifying the value of information is difficult because the value of information changes with circumstances. In particular, information is useful only when it can be acted upon. Up-to-date price information is most useful around harvest time. Crop advisory and input cost information are most useful at planting time. For information to be useful it must be provided in a timely manner. How valuable information is depends on the context: because information is not useful in one year does not imply that it is never useful.

Second, information circulates through channels other than RML — farmers visit markets and talk to each other and to commission agents. For models (7), (8), and (9) to identify the impact of RML information, the circulation of information among farmers must not be so rapid and widespread that control farmers benefit from it as well. For this reason we regard the village as the most appropriate treatment unit, because information exchange is more likely among neighbors. We cannot, however, entirely rule out the possibility of spillovers across villages.

Third, price information may benefit farmers by improving their bargaining power with traders and commission agents. Since the latter cannot easily distinguish between RML and non-RML farmers, it is possible that they adapt their behavior toward all farmers, for instance, by making better price offers. If this is the case, control farmers may benefit as much as treated farmers from the RML service. There is little we can do to protect against this form of contamination, except check informally how agricultural wholesale prices change over time as farmers become better informed. ${ }^{9}$

\section{The Context and Data}

Take-up of RML by Maharashtra farmers is a revealed preference measure of the benefits from the service. We report in Table 1 the number of agricultural holdings in each study districts (2000/01 agricultural census) and the number of RML subscribers over the study period. RML take-up has varied over time. Take-up increased rapidly in all five districts between 2007, the time at which RML was introduced, and 2009, the time at which our experiment started. Take-up never exceeded 0.5 percent of the total farmer population, however. The table also shows that subscription levels have stabilized in recent years and have even come down in some districts in 2010. It is only in Nashik that we see a large increase in the number of subscribers between 2009 and 2010. This may be explained by Nashik having a nascent grape-growing and wine-making

9. It is also conceivable (albeit unlikely) that RML clients indirectly create a negative externality for nonclients, for instance, because the selling behavior of RML clients indirectly lowers the price received by nonclients, or because it raises the price for local consumers. If this were the case, we would overestimate the effect of RML by comparing RML and non-RML farmers within the same village. This is why we focus our analysis on comparisons across treatment and control villages. 
TABLE 1. Number of agricultural holdings and RML subscribers in the five districts studied in Maharashtra

\begin{tabular}{|c|c|c|c|c|c|c|}
\hline \multirow[b]{2}{*}{ District: } & \multirow{2}{*}{$\begin{array}{l}\text { Crop followed } \\
\text { in survey }\end{array}$} & \multirow{2}{*}{$\begin{array}{c}\text { Number of agricultural } \\
\text { holdings* }\end{array}$} & \multicolumn{4}{|c|}{ Number of RML subscribers*** } \\
\hline & & & 2007 & 2008 & 2009 & 2010 \\
\hline Ahmadnag & onion & 916,724 & 711 & 1,377 & 3,763 & 1,637 \\
\hline Dhule & wheat & 230,216 & 108 & 1,296 & 1,028 & 840 \\
\hline Latur & soya & 305,706 & 163 & 914 & 1,048 & 826 \\
\hline Nashik & pomegranate & 591,763 & 2,176 & 1,561 & 3,934 & 6,514 \\
\hline Pune & tomato & 667,365 & 392 & 653 & 3,495 & 781 \\
\hline Total & & $2,711,774$ & 3,550 & 5,801 & 13,268 & 10,598 \\
\hline
\end{tabular}

*: Government of India, Agricultural Census, 2000/01.

*:: Thompson-Reuters.

industry that has been rapidly growing in recent years. Since grapes are grown primarily by large farmers, they are not included in our study.

Next we report on contamination and noncompliance. Extensive contamination could indicate that many farmers find RML beneficial and sought it out even though it was not marketed locally. In contrast, extensive noncompliance could suggest that treated farmers did not find the service useful. In Table 2 we compare the experimental design, or intent to treat, in the two upper panels to actual RML usage in the lower panel. The uppermost panel describes the original experimental design. This design assumes that 10 farmers would be found in each of the 100 villages selected for the study.

The middle panel of Table 2 describes how the experiment was implemented in practice. This represents what in the rest of the paper we call intent to treat. All farmers in treatment 1 villages were offered RML free of charge for one year. In control villages, no farmer was offered RML and no marketing of RML was done by Thompson-Reuters. In treatment 2 villages, a randomly selected subset of farmers (3 out of 10) were offered RML and the others were not.

There was some attrition between the baseline and follow-up surveys: of the 1,000 farmers interviewed in the baseline, 933 were revisited in the follow-up survey. There is some difference in attrition between the control and treatment groups, that is, 91 percent versus 96 percent versus 93 percent. To investigate whether there is anything systematic about attrition, we regressed an attrition dummy on household characteristics. ${ }^{10}$ We find that onion producers (Ahmadnagar district) are more likely to drop out of the experiment, but none of the other variables is statistically significant. Triplet dummies are included as regressors throughout the analysis; they indirectly control for district/target crop.

10. That is, household size, age of household head, education of household head, land owned, total land cultivated of the selected crop in 2009, and target crop/district dummies. 
TABle 2. Compliance and contamination

\begin{tabular}{|c|c|c|c|c|c|c|c|c|c|}
\hline & \multicolumn{3}{|c|}{ All villages } & \multirow{2}{*}{\multicolumn{2}{|c|}{$\frac{\text { Treatment } 1}{\text { RML }}$}} & \multirow{2}{*}{\multicolumn{2}{|c|}{$\frac{\text { Treatment } 2}{\text { RML }}$}} & \multirow{2}{*}{\multicolumn{2}{|c|}{$\frac{\text { Control }}{\text { RML }}$}} \\
\hline & \multirow{2}{*}{$\begin{array}{l}\text { Number } \\
\text { of villages }\end{array}$} & \multicolumn{2}{|c|}{ RML } & & & & & & \\
\hline & & yes & no & yes & no & yes & no & yes & no \\
\hline Intended experimental design & \multicolumn{9}{|c|}{ Number of households } \\
\hline All & 100 & 455 & 545 & 350 & 0 & 105 & 245 & 0 & 300 \\
\hline Tomato growers & 20 & 91 & 109 & 70 & 0 & 21 & 49 & 0 & 60 \\
\hline Pomegranate growers & 20 & 91 & 109 & 70 & 0 & 21 & 49 & 0 & 60 \\
\hline Onion growers & 20 & 91 & 109 & 70 & 0 & 21 & 49 & 0 & 60 \\
\hline Wheat growers & 20 & 91 & 109 & 70 & 0 & 21 & 49 & 0 & 60 \\
\hline Soya growers & 20 & 91 & 109 & 70 & 0 & 21 & 49 & 0 & 60 \\
\hline \multicolumn{10}{|l|}{$\begin{array}{l}\text { Realized design or } \\
\text { intent to treat }\end{array}$} \\
\hline All & 100 & 422 & 511 & 325 & 0 & 97 & 239 & 0 & 272 \\
\hline Tomato growers & 20 & 84 & 107 & 64 & 0 & 20 & 49 & 0 & 58 \\
\hline Pomegranate growers & 20 & 89 & 107 & 68 & 0 & 21 & 52 & 0 & 55 \\
\hline Onion growers & 20 & 88 & 105 & 68 & 0 & 20 & 49 & 0 & 56 \\
\hline Wheat growers & 20 & 86 & 102 & 67 & 0 & 19 & 47 & 0 & 55 \\
\hline Soya growers & 20 & 75 & 90 & 58 & 0 & 17 & 42 & 0 & 48 \\
\hline \multicolumn{10}{|c|}{ RML usage (from 2010 survey and phone interview) } \\
\hline All households & 100 & 247 & 686 & 181 & 144 & 56 & 280 & 10 & 262 \\
\hline Tomato growers & 20 & 44 & 147 & 35 & 29 & 9 & 60 & 0 & 58 \\
\hline Pomegranate growers & 20 & 65 & 131 & 42 & 26 & 19 & 54 & 4 & 51 \\
\hline Onion growers & 20 & 44 & 149 & 36 & 32 & 8 & 61 & 0 & 56 \\
\hline Wheat growers & 20 & 48 & 140 & 33 & 34 & 11 & 55 & 4 & 51 \\
\hline Soya growers & 20 & 46 & 119 & 35 & 23 & 9 & 50 & 2 & 46 \\
\hline \multicolumn{10}{|l|}{ Extension agents: } \\
\hline Intended design & & 30 & 70 & 15 & 20 & 15 & 20 & 0 & 30 \\
\hline Realized design & & 20 & 80 & 10 & 25 & 10 & 25 & 0 & 30 \\
\hline
\end{tabular}

In the next panel we report actual RML usage, as depicted by the 2010 survey and by the ex post phone interview. We note a significant proportion of noncompliers: only 59 percent of those farmers who were offered RML actually used it. Non-usage has various proximate causes. Some subscribers simply refused the service. In the ex post phone interview, respondents were asked the reason for refusal. Some indicated that they believed they would be charged for service later on; others were illiterate households who could not read SMS messages and thus could not use the service anyway. Another reason for non-usage was that subscribers never activated the RML service. To activate it, the subscriber had to select three crops and markets; some subscribers never completed the activation sequence. Non-usage was also partly due to changes in phone number or to migration-for example, a household member leaving the farm and taking the phone number with them. The RML service is tied to a specific phone number, so if this phone number is no longer used by the household, the service no longer reaches its intended target. Finally, a number of 
Chinese-made phones could not display the Marathi script and households with such phones could not read the RML messages. Although there is variation between them, all these proximate causes indicate a certain lack of interest in the service: if RML had been valuable, recipients would have made more effort to secure it-for example, by keeping the SIM card and getting another phone.

There is variation in noncompliance across districts: Noncompliance is lowest in Nashik among pomegranate farmers (27 percent). This finding is consistent with the high take-up reported in Table 1, and indicates more interest in RML in that district. In contrast, the proportion of noncompliers is close to half among onion, tomato, and wheat growers. While noncompliance is high, contamination is low everywhere: only 3.7 percent of control farmers-10 out of 272 farmers-signed up for RML. This confirms that interest in the service among study farmers is limited.

At the bottom of Table 2 we report variation between the intended experimental design and the realized treatment for extension agents. The intent was to offer one year of RML service free of charge to the extension agents serving a randomly selected subsample of 30 of the 70 treated villages. In practice, we only managed to locate and offer RML to extension agents serving 20 of the treated villages. In order not to introduce contamination, RML was not offered to extension agents serving control villages. This means that we can only measure the additional effect that an informed extension agent may have over and above an individual RML contract (treatment 1 villages) or in addition to treatment of other farmers in the same village (control farmers in treatment 2 villages).

In Table 3 we compare control and intent-to-treat farmers in terms of balance. Columns 4 and 5 report the mean value of each variable for the control group and their standard deviation, respectively. Columns 6 and 7 report the coefficient of an intent-to-treat dummy in a regression of each variable on triplet fixed effects. ${ }^{11}$ Reported coefficients suggest good balance on all variables, including area planted to the target crop, marketing, transaction costs, past weather, and past technological innovation. We follow Deaton's (2009) suggestion not to include unnecessary control variables in the analysis of randomized controlled trials (RCTs), as it may artificially inflate t-values.

\section{Empirical Analysis}

We now turn to the econometric analysis. Unless otherwise stated, all analysis is conducted in terms of intent to treat, that is, the treated are those who were offered a free one-year subscription to the RML, whether or not they used it. We also report local average treatment effect (LATE) results in which we instrument actual RML usage with random assignment to treatment. We refer to

11. Bruhn and McKenzie (2009) indicate that fixed effects for each stratification cell should be included in all regressions. 
TABLE 3. Balancedness of treatment versus control in the 2009 baseline data

\begin{tabular}{|c|c|c|c|c|c|c|}
\hline & \multirow[b]{2}{*}{ Unit } & \multirow{2}{*}{$\begin{array}{c}\text { Number } \\
\text { of } \\
\text { observation }\end{array}$} & \multicolumn{2}{|c|}{ Control group } & \multicolumn{2}{|c|}{ Treatment* } \\
\hline & & & Mean & St. Dev. & Coeff. & t-value \\
\hline \multicolumn{7}{|l|}{ Household characteristics } \\
\hline Education level head of household & years & 911 & 8.19 & 4.36 & 0.243 & 0.68 \\
\hline Household size & number & 933 & 6.43 & 2.70 & 0.131 & 0.61 \\
\hline Share of children in household & share & 933 & 0.26 & - & -0.008 & -0.72 \\
\hline Share of elderly in household & share & 933 & 0.08 & - & 0.011 & 1.38 \\
\hline Age head of household & years & 922 & 49.51 & 12.93 & 0.409 & 0.42 \\
\hline Farm experience & years & 930 & 26.86 & 13.92 & -0.379 & -0.39 \\
\hline \multicolumn{7}{|l|}{ Land ownership and cultivation } \\
\hline Land owned & acres & 933 & 9.62 & 8.62 & 0.677 & 0.64 \\
\hline Land cultivated of tomato in Pune & acres & 191 & 1.79 & 3.01 & -0.154 & -0.40 \\
\hline Land cultivated of pomegranate in Nashik & acres & 196 & 3.64 & 3.50 & 0.508 & 0.62 \\
\hline Land cultivated of onions in Ahmadnagar & acres & 193 & 2.06 & 1.87 & 0.258 & 0.65 \\
\hline Land cultivated of wheat in Dhule & acres & 188 & 5.76 & 3.95 & -1.073 & -1.65 \\
\hline Land cultivated of soya in Latur & acres & 165 & 5.76 & 4.09 & 0.841 & 0.39 \\
\hline Total crop area cultivated & acres & 933 & 14.78 & 13.04 & 1.340 & 0.88 \\
\hline \multicolumn{7}{|l|}{ Marketing characteristics studied crop } \\
\hline \multicolumn{7}{|l|}{ Know market price of studied crop: } \\
\hline - the day before he sold it & share & 910 & 0.78 & - & 0.037 & 1.13 \\
\hline - the week before he sold it & share & 912 & 0.38 & - & 0.070 & 1.58 \\
\hline - a month before he sold it & share & 912 & 0.08 & - & 0.029 & 1.33 \\
\hline - when he planted it & share & 912 & 0.06 & - & 0.020 & 1.67 \\
\hline \multicolumn{7}{|l|}{ For each transaction: } \\
\hline - Prices obtained in each transaction & $\mathrm{Rs} / \mathrm{kg}$ & 1563 & 13.22 & 10.20 & -0.149 & -0.44 \\
\hline - Quantities sold per transaction & $\log (\mathrm{kgs})$ & 1563 & 7.11 & 1.57 & -0.067 & -0.75 \\
\hline - Produce is sold in the village & share & 1554 & 0.15 & - & -0.016 & -0.57 \\
\hline - Head of household made sale & share & 1561 & 0.85 & - & -0.021 & -0.58 \\
\hline - Crop was graded/sorted before sale & share & 1561 & 0.70 & - & 0.036 & 0.84 \\
\hline $\begin{array}{l}\text { - Produce is sold through commission } \\
\text { agent }\end{array}$ & share & 1555 & 0.40 & - & 0.032 & 0.83 \\
\hline Number of sale transactions per farmer & number & 894 & 1.74 & 1.19 & -0.001 & -0.01 \\
\hline \multicolumn{7}{|l|}{ Transaction costs last transaction } \\
\hline Paid for transport of produce & share & 908 & 0.88 & - & 0.013 & 0.45 \\
\hline Paid for personal transport & share & 797 & 0.11 & - & 0.022 & 0.90 \\
\hline Sold through commission agent & share & 905 & 0.57 & - & -0.036 & -0.80 \\
\hline \multicolumn{7}{|l|}{ Weather in 12 months prior to survey } \\
\hline Did not incur storm/heavy rainfall & share & 933 & 0.53 & - & -0.021 & -0.63 \\
\hline \multicolumn{7}{|c|}{ Technology changes in 12 months prior to survey } \\
\hline Changed crop varieties & share & 933 & 0.34 & - & -0.020 & -0.57 \\
\hline Changed cultivation practices & share & 933 & 0.28 & - & -0.004 & -0.11 \\
\hline
\end{tabular}

All variables refer to 2009 data.

*village triplet code dummies and intercept included but not reported. 
these results as IV or LATE estimates interchangeably. For much of the analysis we use both treatment 1 and treatment 2 farmers to improve efficiency. When using treatment 2 farmers, the intent-to-treat variable is set to 1 if a surveyed farmer in a treatment 2 village was randomly assigned to treatment, and 0 otherwise. All reported standard errors are clustered by village triplet (see experimental design section).

\section{RML Usage}

We begin with RML usage as reported by farmers. In the baseline survey all respondents were asked to list their main sources of information for agricultural prices, weather forecast, and advice on agricultural practices. Answers are tabulated in Table A.1 in the supplemental appendix. Own observation/experimentation is the main source of information reported by all respondents, followed by conversations with other farmers. Radio and television are mentioned as a common source of information on the weather, less so for crop prices. RML is not mentioned by anyone.

In the top panel of Table 4 we report the average difference in the proportion of respondents who mention RML as a source of information in the ex post survey. The average treatment effect on the treated (ATT) is calculated using the nearest neighbor-matching methodology described in Abadie at al. (2004), where matching is performed by triplet dummy. Reassuringly, treated farmers are significantly more likely to mention RML in all six categories. The difference is largest in magnitude for prices and weather, which are the primary focus of the RML service: 24 percent and 23 percent more treated respondents mention RML as a source of information on crop prices and weather forecasts, respectively.

LATE-IV estimates are reported in the next panel of Table 4. These estimates are obtained using regression analysis. Dummies are included for village selection triplets. Since contamination is low (3.7 percent) but noncompliance is high (41 percent), we expected instrumented treatment effects to be larger than the intent-to-treat effect reported at the top of the table. This is indeed what happens: We now find that farmers who were induced to use RML as a result of treatment are 46 percent more likely to mention RML as a source of information on crop prices. The corresponding figures for weather prediction and for input use are 44 percent and 39 percent, respectively. This suggests that RML is seen as a source of information by a large proportion of participating farmers. Yet, the effect is not 100 percent, which means that, since non-users do not list RML, a sizable portion of treated respondents do not list RML as a source of information.

In the second part of the table we look for evidence of heterogeneous effects by farmer age and farm size. We estimate regression (3) with triplet fixed effects as suggested by Bruhn and McKenzie (2009). Farmers cultivating a larger area are significantly more likely to mention RML as a source of 
TABLE 4. Use of RML

\begin{tabular}{|c|c|c|c|c|c|c|c|}
\hline \multirow[b]{2}{*}{ Whole sample } & & \multicolumn{6}{|c|}{ Use RML as one of the sources of information for: } \\
\hline & & $\begin{array}{l}\text { Crop } \\
\text { prices }\end{array}$ & $\begin{array}{l}\text { Weather } \\
\text { prediction }\end{array}$ & $\begin{array}{l}\text { Crops to } \\
\text { plant }\end{array}$ & $\begin{array}{l}\text { Cultivation } \\
\text { practices }\end{array}$ & $\begin{array}{l}\text { input use } \\
\text { (d) }\end{array}$ & $\begin{array}{c}\text { post-harvest } \\
\text { practices }\end{array}$ \\
\hline \multicolumn{2}{|l|}{$\begin{array}{l}\text { Number of } \\
\text { observations }\end{array}$} & 925 & 931 & 925 & 925 & 918 & 924 \\
\hline \multicolumn{8}{|c|}{ Nearest neighbor matching (a) } \\
\hline \multirow[t]{2}{*}{ ATT } & Coeff & 0.243 & 0.231 & 0.106 & 0.086 & 0.200 & 0.054 \\
\hline & z-value & 10.600 & 10.530 & 6.550 & 5.390 & 9.360 & 3.970 \\
\hline \multicolumn{8}{|c|}{ Regression results $(b)$} \\
\hline \multirow[t]{2}{*}{ Treatment } & Coeff & 0.463 & 0.439 & 0.206 & 0.172 & 0.386 & 0.113 \\
\hline & t-value & 10.460 & 10.530 & 5.230 & 4.710 & 8.940 & 3.220 \\
\hline \multirow[t]{2}{*}{ Intercept } & Coeff & 0.007 & -0.021 & -0.008 & -0.001 & -0.044 & 0.044 \\
\hline & t-value & 0.840 & -2.530 & -1.000 & -0.150 & -5.080 & 6.300 \\
\hline \multicolumn{8}{|c|}{ 2. Heterogeneous effects (c) } \\
\hline \multirow[t]{2}{*}{ Treatment } & Coeff & 0.239 & 0.225 & 0.107 & 0.089 & 0.198 & 0.057 \\
\hline & t-value & 8.760 & 9.330 & 5.580 & 4.880 & 8.140 & 3.160 \\
\hline \multirow[t]{2}{*}{ Intercept } & Coeff & -0.034 & -0.470 & -0.034 & -0.026 & -0.066 & 0.027 \\
\hline & t-value & -1.950 & -2.770 & -2.450 & -1.870 & -4.320 & 2.000 \\
\hline \multirow{2}{*}{$\begin{array}{l}\text { Dummy young } \\
\text { head of } \\
\text { household }\end{array}$} & Coeff & 0.024 & 0.022 & 0.007 & 0.005 & 0.014 & -0.003 \\
\hline & t-value & 1.270 & 1.670 & 0.650 & 0.450 & 1.520 & -0.300 \\
\hline \multirow{2}{*}{$\begin{array}{c}\text { Total crop area } \\
\text { cultivated }\end{array}$} & Coeff & 0.001 & -0.000 & 0.001 & 0.001 & 0.000 & 0.001 \\
\hline & t-value & 1.200 & -0.020 & 1.700 & 1.890 & 0.430 & 1.680 \\
\hline \multicolumn{8}{|c|}{ Interaction with treatment } \\
\hline \multirow{2}{*}{$\begin{array}{l}\text { Dummy young } \\
\text { head of } \\
\text { household }\end{array}$} & Coeff & 0.045 & 0.018 & 0.057 & 0.019 & 0.007 & 0.034 \\
\hline & t-value & 1.040 & 0.390 & 1.580 & 0.530 & 0.150 & 1.210 \\
\hline \multirow{2}{*}{$\begin{array}{l}\text { Total crop area } \\
\text { cultivated }\end{array}$} & Coeff & 0.002 & 0.004 & -0.000 & -0.001 & 0.002 & -0.000 \\
\hline & t-value & 2.340 & 4.300 & -0.060 & -0.700 & 2.110 & -0.380 \\
\hline
\end{tabular}

(a) Matching based on village triplet code dummies

(b) Village triplet code dummies included but not reported

(c) Mean value substracted from those control variables interacted with treatment

(d) fertilizers, pesticides, and herbicides

t-values based on standard errors clustered by village triplet code;

$\mathrm{t}$-values in bold significant at the $10 \%$ level or better.

information. This effect is limited to treated large farmers for crop prices, weather predictions, and input use. Farmer age is never significant.

Next we examine whether treated farmers appear more knowledgeable about crop prices. In the first four columns of results in Table 5, we present ATT estimates for knowing the sale price of the target crop before the day of the sale. Results show that treated farmers consider themselves more knowledgeable about crop prices in general. The difference is significant in all four cases, that is, one day before sale as well as several months before sale. In the second panel of Table 5 we report IV-LATE estimates that, as for Table 4, are 
TAвLE 5. Knowledge and information sharing

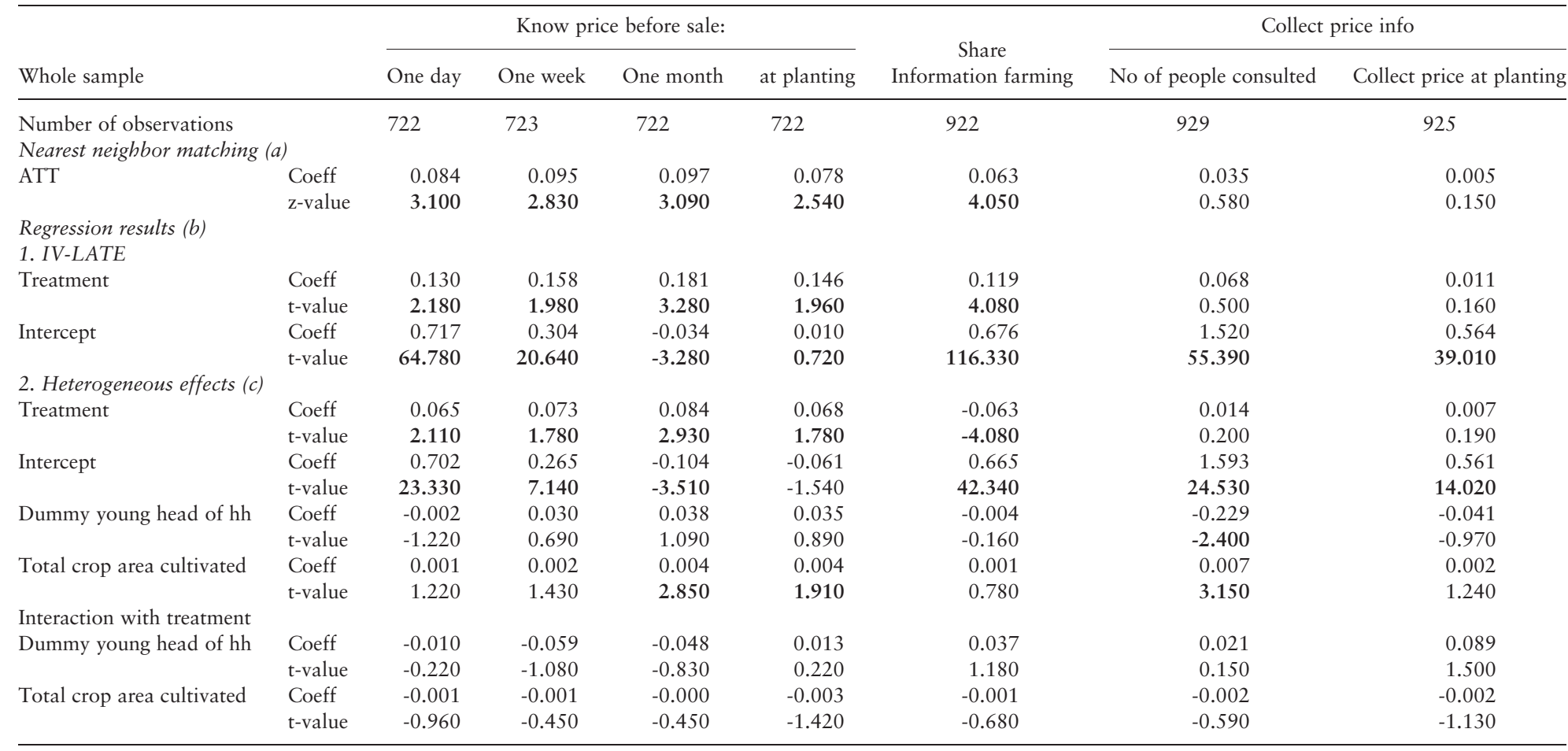

(a) Matching based on village triplet code dummies.

(b) Village triplet code dummies included but not reported.

(c) Mean value substracted from those control variables interacted with treatment.

$t$-values based on standard errors clustered by village triplet code;

$\mathrm{t}$-values in bold significant at the $10 \%$ level or better. 
larger in magnitude than the intent-to-treat ATT. There is no evidence of heterogeneous effect along those two dimensions.

In the next column of Table 5 we investigate whether treated farmers report sharing more information about farming with other farmers. If RML information is valuable, we expect treated farmers to be more likely to share it with others. Results reported in Table 5 suggest that this is indeed the case, but the effect is not large in magnitude: the intent-to-treat estimated ATT is a 6 percent increase; the IV-LATE estimate is larger at 12 percent, but still relatively small. Both effects are statistically significant, however. There is no evidence of heterogeneous effects by farm size or farmer age.

In the last two columns of Table 5 we check whether treated farmers economize on search costs because of RML. To this effect, we examine whether treated farmers make less effort gathering price information, either by consulting with others or by collecting price information in person at the time of planting. Contrary to expectations, results do not suggest this to be the case. The heterogeneous effect regression results reported at the bottom of the table indicate that large farmers consult with more people and are more likely to collect price information at planting time. For these farmers, the gain from making a better informed decision are larger, hence more effort is made to gather relevant price information. But we find no significant evidence that RML helps large farmers economize on these costs. This may only be temporary, however: once farmers learn they can trust RML information they may decide to rely on it more. Young farmers consult fewer people about prices, but there is no evidence of heterogeneous treatment effects by farmer age.

\section{Price Received}

There is considerable price variation within villages. Different crops have different coefficients of variation: lower for nonperishable crops such as wheat $(\mathrm{CV}=0.07)$ and soya $(\mathrm{CV}=0.14)$, and higher for perishable crops such as tomatoes $(\mathrm{CV}=0.22)$, onions $(0.44)$, and pomegranates $(0.45)$. We thus expect RML to be particularly beneficial for more perishable crops since their prices are more volatile and information is potentially more valuable.

This is what we investigate in Table 6. The dependent variable is the log of the unit price received by the respondent on average over all the sales transactions of the target crop during the 12 months preceding the survey. Similar results are obtained if we use the price level instead of the log. The unit of observation is the sales transaction. Most farmers report a single sale but some report more than one, which explains why the number of observations exceeds the number of participating farmers.

The first column of Table 6 reports the ATT obtained using nearest neighbor matching. Contrary to expectations, we find no beneficial effect of the treatment on price received: the treatment effect is negative and statistically significant. We worry that this may be due to the inclusion of treatment 2 villages in the comparison. Indeed, in these villages, the small number of randomly 
TAble 6. Prices obtained (expressed in $\log (\mathrm{Rs} / \mathrm{kg})$ )

\begin{tabular}{|c|c|c|c|c|c|c|c|}
\hline & & \multirow{2}{*}{$\operatorname{ATT}(\mathrm{a})$} & \multirow{2}{*}{ ATT (b) } & \multirow{2}{*}{ IV-LATE } & \multirow{2}{*}{$\begin{array}{c}\text { OLS } \\
\text { long-model(c) }\end{array}$} & \multicolumn{2}{|c|}{$\begin{array}{l}\text { Heterogeneous } \\
\text { effects (d) }\end{array}$} \\
\hline & & & & & & OLS & IV \\
\hline $\begin{array}{l}\text { For whole } \\
\text { sample(e) }\end{array}$ & No obs. & 1480 & 688 & 1480 & 1425 & 1464 & 1457 \\
\hline Treatment & $\begin{array}{l}\text { Coeff } \\
t \text {-value }\end{array}$ & $\begin{array}{l}-0.031 \\
-2.000\end{array}$ & $\begin{array}{l}-0.043 \\
-0.520\end{array}$ & $\begin{array}{l}-0.062 \\
-1.670\end{array}$ & $\begin{array}{l}-0.028 \\
-1.510\end{array}$ & $\begin{array}{l}-0.034 \\
-1.860\end{array}$ & $\begin{array}{l}-0.026 \\
-1.430\end{array}$ \\
\hline Intercept & $\begin{array}{l}\text { Coeff } \\
\text { t-value }\end{array}$ & & & $\begin{array}{r}2.260 \\
309.620\end{array}$ & $\begin{array}{r}2.159 \\
21.250\end{array}$ & $\begin{array}{l}2.248 \\
93.64\end{array}$ & $\begin{array}{r}2.249 \\
99.080\end{array}$ \\
\hline $\begin{array}{l}\text { Dummy young } \\
\text { head of hh }\end{array}$ & $\begin{array}{l}\text { Coeff } \\
\text { t-value }\end{array}$ & & & & $\begin{array}{l}0.021 \\
0.990\end{array}$ & $\begin{array}{l}-0.013 \\
-0.500\end{array}$ & $\begin{array}{l}-0.013 \\
-0.530\end{array}$ \\
\hline $\begin{array}{l}\text { Total crop area } \\
\text { cultivated }\end{array}$ & $\begin{array}{l}\text { Coeff } \\
\text { t-value }\end{array}$ & & & & $\begin{array}{l}0.005 \\
5.720\end{array}$ & $\begin{array}{l}0.001 \\
1.900\end{array}$ & $\begin{array}{l}0.001 \\
1.550\end{array}$ \\
\hline $\begin{array}{l}\text { Dummy if sold } \\
\text { to a trader }\end{array}$ & $\begin{array}{l}\text { Coeff } \\
\text { t-value }\end{array}$ & & & & $\begin{array}{l}-0.011 \\
-0.250\end{array}$ & $\begin{array}{l}-0.006 \\
-0.190\end{array}$ & $\begin{array}{l}-0.008 \\
-0.290\end{array}$ \\
\hline $\begin{array}{l}\text { Treatment } \\
\text { extension } \\
\text { agent }\end{array}$ & $\begin{array}{l}\text { Coeff } \\
\text { t-value }\end{array}$ & & & & $\begin{array}{l}-0.013 \\
-0.500\end{array}$ & & \\
\hline Interaction with & treatment & & & & & & \\
\hline $\begin{array}{l}\text { Dummy young } \\
\text { head of hh }\end{array}$ & $\begin{array}{l}\text { Coeff } \\
\text { t-value }\end{array}$ & & & & & $\begin{array}{l}0.057 \\
1.750\end{array}$ & $\begin{array}{l}0.059 \\
1.850\end{array}$ \\
\hline $\begin{array}{l}\text { Total crop area } \\
\text { cultivated }\end{array}$ & $\begin{array}{l}\text { Coeff } \\
t \text {-value }\end{array}$ & & & & & $\begin{array}{l}-0.001 \\
-0.590\end{array}$ & $\begin{array}{l}-0.000 \\
-0.240\end{array}$ \\
\hline $\begin{array}{l}\text { Dummy if sold } \\
\text { to a trader }\end{array}$ & $\begin{array}{l}\text { Coeff } \\
\text { t-value }\end{array}$ & & & & & $\begin{array}{l}0.085 \\
1.750\end{array}$ & $\begin{array}{l}0.091 \\
1.830\end{array}$ \\
\hline $\begin{array}{l}\text { For control/ } \\
\text { treatment } 1 \\
\text { village }\end{array}$ & No obs. & 947 & 443 & 947 & 909 & 938 & 931 \\
\hline Treatment & $\begin{array}{l}\text { Coeff } \\
t \text {-value }\end{array}$ & $\begin{array}{l}-0.015 \\
-0.600\end{array}$ & $\begin{array}{l}0.031 \\
0.630\end{array}$ & $\begin{array}{l}-0.079 \\
-1.600\end{array}$ & $\begin{array}{l}-0.017 \\
-0.510\end{array}$ & $\begin{array}{l}-0.046 \\
-1.740\end{array}$ & $\begin{array}{l}-0.032 \\
-1.170\end{array}$ \\
\hline Intercept & $\begin{array}{l}\text { Coeff } \\
\text { t-value }\end{array}$ & & & $\begin{array}{r}2.211 \\
147.890\end{array}$ & $\begin{array}{r}2.071 \\
15.100\end{array}$ & $\begin{array}{r}2.218 \\
61.610\end{array}$ & $\begin{array}{r}2.209 \\
59.530\end{array}$ \\
\hline $\begin{array}{l}\text { Dummy young } \\
\text { head of hh }\end{array}$ & $\begin{array}{l}\text { Coeff } \\
\text { t-value }\end{array}$ & & & & $\begin{array}{l}0.016 \\
0.490\end{array}$ & $\begin{array}{l}-0.014 \\
-0.410\end{array}$ & $\begin{array}{l}-0.013 \\
-0.360\end{array}$ \\
\hline $\begin{array}{l}\text { Total crop area } \\
\text { cultivated }\end{array}$ & $\begin{array}{l}\text { Coeff } \\
\text { t-value }\end{array}$ & & & & $\begin{array}{l}0.005 \\
2.940\end{array}$ & $\begin{array}{l}0.001 \\
0.950\end{array}$ & $\begin{array}{l}0.001 \\
0.800\end{array}$ \\
\hline $\begin{array}{c}\text { Dummy if sold } \\
\text { to a trader }\end{array}$ & $\begin{array}{l}\text { Coeff } \\
\text { t-value }\end{array}$ & & & & $\begin{array}{l}-0.053 \\
-0.970\end{array}$ & $\begin{array}{l}-0.020 \\
-0.770\end{array}$ & $\begin{array}{l}-0.016 \\
-0.510\end{array}$ \\
\hline $\begin{array}{l}\text { Treatment } \\
\text { extension } \\
\text { agent }\end{array}$ & $\begin{array}{l}\text { Coeff } \\
\text { t-value }\end{array}$ & & & & $\begin{array}{l}-0.048 \\
-1.000\end{array}$ & & \\
\hline
\end{tabular}


TABLE 6. Continued

\begin{tabular}{|c|c|c|c|c|c|c|}
\hline & & \multirow{2}{*}{$\operatorname{ATT}(\mathrm{a})$} & IV-LATE & \multirow{2}{*}{$\begin{array}{c}\text { OLS } \\
\text { long-model(c) }\end{array}$} & \multicolumn{2}{|c|}{$\begin{array}{l}\text { Heterogeneous } \\
\text { effects }(\mathrm{d})\end{array}$} \\
\hline & & & ATT (b) & & OLS & IV \\
\hline \multicolumn{7}{|c|}{ Interaction with treatment } \\
\hline $\begin{array}{l}\text { Dummy young } \\
\text { head of hh }\end{array}$ & $\begin{array}{l}\text { Coeff } \\
\text { t-value }\end{array}$ & & & & $\begin{array}{l}0.041 \\
1.040\end{array}$ & $\begin{array}{l}0.038 \\
0.910\end{array}$ \\
\hline $\begin{array}{l}\text { Total crop area } \\
\text { cultivated }\end{array}$ & $\begin{array}{l}\text { Coeff } \\
\text { t-value }\end{array}$ & & & & $\begin{array}{l}0.000 \\
0.050\end{array}$ & $\begin{array}{l}0.000 \\
0.180\end{array}$ \\
\hline $\begin{array}{l}\text { Dummy if sold } \\
\text { to a trader }\end{array}$ & $\begin{array}{l}\text { Coeff } \\
\text { t-value }\end{array}$ & & & & $\begin{array}{l}0.101 \\
2.210\end{array}$ & $\begin{array}{l}0.093 \\
1.820\end{array}$ \\
\hline
\end{tabular}

(a) impact survey only; using nearest neighborhood matching; the reported coefficient on treatment is the ATT.

(b) diff-in-diff, nearest neighborhood matching; using average unweighted prices in baseline and impact survey.

(c) including but not reported dummies for graded, sold through commission agent, sold to trader, immediate payments, and quantity sold, years of education head of household, social network in village, land owned, years of farm experience, area cultivated of studied crop.

(d) Mean value substracted from those control variables interacted with treatment.

(e) village triplet code dummies included but not reported.

$\mathrm{t}$-values based on standard errors clustered by village triplet code;

$\mathrm{t}$-values in bold significant at the $10 \%$ level or better.

treated farmers may circulate the RML information to untreated farmers, who would then also benefit from it. This may blur the comparison between control and treated farmers due to a confounding externality between control and treated farmers. To investigate whether this explains our result, we re-estimate the ATT using only treatment 1 and control villages. The results are reported in the second panel of Table 6. We again find a negative treatment effect on farmer price, but it is not statistically significant. We also checked (results not reported here to save space) whether farmers in treatment 2 villages received higher prices than in control areas-unsurprisingly, given the lack of result for stronger treatment 1 , they do not. The next column reports dif-in-dif ATT estimates, using nearest neighbor matching. Point estimates are now slightly positive, but nowhere near conventional levels of significance.

Next we examine whether the lack of effect is due to non-compliance. To investigate this possibility, we instrument actual RML usage with the intent-to-treat dummy and report the results in the IV-LATE column of Table 6. The estimated coefficient of receiving the RML service is still negative, but remains non-significant for the entire sample as well as for the sample without treatment 2 villages.

In Table A2 in the supplemental appendix, we repeat the ATT nearest neighbor matching and IV-LATE analysis for each crop separately. For the whole sample, ATT point estimates are negative for all crops, significantly so for 
onions. IV-LATE point estimates remain negative, but are not statistically significant. When we restrict the analysis to control and treatment 1 villages, we find negative ATT and IV point estimates for four out of five crops; except for one (IV for tomatoes), they are not significant.

We then examine whether intent-to-treat results may be affected by omitted variable bias. This is unlikely because treatment is randomly assigned, but we check it anyway. To this effect, we add controls for farmer age and farm size, as well as dummies for type of sale (that is, whether sold in the village or to a trader, as opposed to sold in the local wholesale market or mandi). We also include a dummy equal to one if the extension agent serving the village received the free RML service. Results are reported in Table 6 under the "OLS long model" column. Other controls are included as well, as detailed at the bottom of the table, but their coefficients are not reported to save space. Again we find no evidence of a significant treatment effect. The coefficient of the extension agent treatment is similarly non-significant.

In the last two columns of Table 6 we investigate the possible existence of heterogeneous effects. The OLS columns report the heterogeneous intent-to-treat effect, equation (9), with controls. We also estimate an heterogeneous effect version of equation (8):

$$
Y_{i}=\theta+\alpha S_{i}+\gamma X_{i}+\eta S_{i}\left(X_{i}-\bar{X}\right)+e_{i}
$$

Wooldridge (2002) recommends estimating IV models of this kind as follows. Let $\tilde{S}_{l}$ be the predicted value of $S_{i}$ from the instrumenting equation. We construct a variable $\tilde{S}_{l}\left(X_{i}-\bar{X}\right)$ and we estimate $(10)$ using $\tilde{S}_{l}$ and $\tilde{S}_{l}\left(X_{i}-\bar{X}\right)$ as instruments.

In the OLS (intent-to-treat) results we now find a negative average treatment effect but a positive heterogeneous effect on young farmers. Treated young farmers received a price that is about 6 percent higher on average. In the IV results, the average treatment effect is non-significant, but the heterogeneous age effect remains. This suggests that less experienced farmers gain something from RML. These findings, however, are not robust to dropping treatment 2 villages, as seen in the second panel of Table 6 .

As robustness check, we correct for the possibility of non-random attribution by adding an inverse Mills ratio as additional regressor in the IV-LATE regression. This Mills ratio is obtained from the attrition selection regression mentioned in Section 3. Results, not shown here, are similar to those reported in Table 6, and the Mills ratio is not statistically significant from 0 in the full sample or when using treatment 1 only, suggesting that non-random attrition is unlikely to have affected our findings.

We also find that, in the OLS regression, farmers that grow more of the target crop get a significantly higher price on average. One possible explanation is that, for small crop sales, farmers make less effort to obtain price information and, hence, sell at a lower price. This effect, however, is not robust-it 
disappears in the IV regression or if we drop treatment 2 villages. Finally, consistent with expectations, treated households receive a price that is $8-9$ percent higher than control households when they sell to a trader as opposed to a commission agent. This is in line with the idea that better informed farmers can negotiate better deals from buyers when they sell outside the relative safety of the mandi.

We also examined whether treatment reduced the coefficient of variation of the price received by farmers in the same village. We expect price variation across farmers to be less if they are better informed. Aker (2008), for instance, reports that the introduction of mobile phones in Niger facilitated price integration and reduced price dispersion. We do not find a similar effect for RML: the coefficient of variation of prices in treatment 1 villages is 0.320 ; in control villages it is 0.228 , that is, smaller than in treated villages. The difference, however, is not statistically significant: the $\mathrm{t}$-value $=1.52$, with a $\mathrm{p}$-value of 0.135 .

\section{Costs and Revenues}

RML may affect farmers in ways other than prices. Transaction costs per transaction average $0.84 \mathrm{Rs} / \mathrm{Kg}$. This compares to standard deviations for prices of 2.2, 17.1, 4.6, 0.9, and 3.1 Rs/Kg for tomatoes, pomegranates, onions, wheat, and soya, respectively. There is therefore room for farmers to increase revenues by reducing transaction costs.

In the first column of Table 7, we report ATT and IV estimates for total transaction costs on the farmer's last crop sale. Transaction costs include transport, loading and off-loading, payment at checkpoints, personal transport, processing, and commissions. Point estimates are positive for the whole samplesuggesting that RML raises costs-but they become negative when we only use treatment 1 villages. In both cases, however, point estimates are not significant.

In the next column we investigate whether farmers received a higher net price (defined as the gross price minus the variable transaction costs in the last transaction). Mattoo, Mishra, and Narain (2007) estimate that transport costs per truck in India are between 0.09 to $0.13 \mathrm{Rs} / \mathrm{kg} / 100$ kilometers, which is small relative to total transaction costs. It thus seems that, in transport cost at least, arbitraging over space is not prohibitively expensive relative to other transaction costs. If farmers use RML information to arbitrage across space, they may ship their crop to a more distant market and incur a higher transport cost, but obtain a higher price net of costs, as in Jensen (2007). This is not what we find: results remain resolutely non-significant whether we include treatment 2 villages or not. 
TABLe 7. Profitability measures

\begin{tabular}{|c|c|c|c|c|c|}
\hline & & $\begin{array}{l}\text { Transaction } \\
\text { cost }(\mathrm{c})\end{array}$ & $\begin{array}{l}\text { Net price } \\
\text { (d) }\end{array}$ & $\begin{array}{c}\text { Sale } \\
\text { revenues }\end{array}$ & $\begin{array}{l}\text { Value } \\
\text { added } \\
\text { (e) }\end{array}$ \\
\hline \multicolumn{6}{|l|}{ For whole sample } \\
\hline $\begin{array}{l}\text { Number of } \\
\text { observations }\end{array}$ & & 713 & 713 & 713 & 713 \\
\hline \multicolumn{6}{|c|}{ Nearest neighbor matching (a) } \\
\hline ATT & $\begin{array}{l}\text { Coeff } \\
\text { z-value }\end{array}$ & $\begin{array}{l}0.078 \\
1.420\end{array}$ & $\begin{array}{l}-0.760 \\
-1.480\end{array}$ & $\begin{array}{l}48,247 \\
0.580\end{array}$ & $\begin{array}{l}46,352 \\
0.580\end{array}$ \\
\hline \multicolumn{6}{|c|}{$\begin{array}{l}\text { Regression results }(b) \\
\text { IV-LATE }\end{array}$} \\
\hline Treatment & $\begin{array}{l}\text { Coeff } \\
\text { t-value }\end{array}$ & $\begin{array}{l}0.146 \\
1.050\end{array}$ & $\begin{array}{l}-1.450 \\
-1.730\end{array}$ & $\begin{array}{l}87,074 \\
0.880\end{array}$ & $\begin{array}{l}84,530 \\
0.910\end{array}$ \\
\hline Intercept & $\begin{array}{l}\text { Coeff } \\
\text { t-value }\end{array}$ & $\begin{array}{l}1.576 \\
59.060\end{array}$ & $\begin{array}{l}8.906 \\
55.350\end{array}$ & $\begin{array}{l}66,545 \\
3.500\end{array}$ & $\begin{array}{l}59,235 \\
3.320\end{array}$ \\
\hline \multicolumn{6}{|c|}{ For control/treatment 1 villages } \\
\hline $\begin{array}{l}\text { Number of } \\
\text { observations } \\
\text { Nearest neighbor }\end{array}$ & (a) & 458 & 458 & 458 & 458 \\
\hline ATT & $\begin{array}{l}\text { Coeff } \\
\text { z-value }\end{array}$ & $\begin{array}{l}-0.150 \\
-1.700\end{array}$ & $\begin{array}{l}0.735 \\
1.060\end{array}$ & $\begin{array}{l}143,852 \\
1.190\end{array}$ & $\begin{array}{l}138,311 \\
1.220\end{array}$ \\
\hline \multicolumn{6}{|c|}{ Regression results (b) } \\
\hline Treatment & $\begin{array}{l}\text { Coeff } \\
\mathrm{t} \text {-value }\end{array}$ & $\begin{array}{l}0.159 \\
0.439\end{array}$ & $\begin{array}{l}-0.074 \\
-1.000\end{array}$ & $\begin{array}{l}267,588 \\
1.370\end{array}$ & $\begin{array}{l}260,249 \\
1.410\end{array}$ \\
\hline Intercept & $\begin{array}{l}\text { Coeff } \\
\mathrm{t} \text {-value }\end{array}$ & $\begin{array}{l}1.602 \\
25.230\end{array}$ & $\begin{array}{l}1.977 \\
84.880\end{array}$ & $\begin{array}{l}-22,749 \\
-0.370\end{array}$ & $\begin{array}{l}-27,914 \\
-0.480\end{array}$ \\
\hline
\end{tabular}

(a) Matching based on village triplet code dummies.

(b) Village triplet code dummies included but not reported.

(c) last transaction only; includes costs for transport, loading, off-loading, payments at checkpoint/toll or road-block, personal transport, processing, commission expressed in Rs/kg.

(d) last transaction only; gross price minus transaction costs expressed in Rs/kg.

(e) sales minus monetary input costs (fertilizer, pesticides, spray, purchased seeds, manure).

$\mathrm{t}$-values based on standard errors clustered by village triplet code;

$\mathrm{t}$-values in bold significant at the $10 \%$ level or better.

Farmers may gain not on the unit price but on total revenue. This is investigated in column 3. We find large positive point estimates, but no significant effect. $^{12}$ If we use logs instead to limit the influence of outliers, we again find no significant effect. The last column reports similar results for value-added, that is, revenues minus monetary input costs such as fertilizer and pesticides. If weather information and crop advisories raise farmers' technical and allocative efficiency, we would expect value-added to rise. Results are similar to those for

12. Sale values are large because quantities sold are large. This is especially true for onions and pomegranates where the average size of a single transaction is 10 metric tons. There is, however, a lot of variation around this average. 
sale revenues: large positive point estimates, but nothing statistically significant. Similar findings obtain if we use logs instead.

\section{Marketing}

In the conceptual section we argued that if RML is used by farmers to increase the price they receive, we should observe differences in marketing practices. If price information makes enables farmers to arbitrage across markets, we should observe systematic changes in where farmers sell.

We first note that most sales take place in a market, nearly always a wholesale market or mandi. The only exceptions are pomegranates for which, at baseline, 44 percent of sales are conducted at the farm-gate and, to a lesser extent, wheat, with 7 percent of farm-gate sales. For the other crops, farm-gate sales represent less than 2 percent of recorded sales. Second, market diversification varies from crop to crop. Sales of perishable crops are geographically concentrated: 98 percent and 81 percent of all market sales of tomatoes and pomegranates, respectively, occur at a single district market. Concentration is less for other crops: for onions, 51 percent of sales go to one district market. Corresponding figures for wheat and soya are 54 percent and 57 percent, respectively.

To investigate whether treatment changed where farmers sell their crops, we construct an overlap index that captures the extent to which a farmer sold to the same location in the baseline and follow-up surveys. There are 39 wholesale markets listed in the data, with farm-gate sales treated as a separate location. The index is weighted by quantity. An index value of 1 means the farm sold in the same location in the two survey rounds; a value of 0 means that nothing was sold at the same place. We also construct an added market dummy, which takes value 1 if the farmer sold in a new market or location in the follow-up survey, and a dropped market dummy equal to 1 if the farmer stopped selling in a specific location in the second round.

Average treatment effects for the market overlap index and for the added and dropped market dummies are reported in Table 8. In the top panel we use the entire sample; in the second panel we only use the treatment 1 and control samples. With the entire sample treatment has a significant effect: treated farmers are 10 percentage points more likely to add a new sales location (market or farm-gate) and 9 percentage points more likely to drop one sales location. Treatment also reduces the overlap index by 10 percent on average. When we instrument RML usage with assignment to treatment, point estimates double and remain significant. These results are consistent with the predictions of the arbitrage model although, as we have seen in the previous two subsections, changing sales location does not appear to have resulted in a higher price on average. Point estimates are also slightly smaller when we limit the sample to treatment 1 and control villages (second panel of Table 8), but they are no longer statistically significant at the 10 percent level, perhaps because of the reduction in sample size. 
TABLE 8. Spatial arbitrage and market changes

\begin{tabular}{|c|c|c|c|c|}
\hline & & \multicolumn{2}{|c|}{ Number of markets } & \multirow[b]{2}{*}{ Overlap index (c) } \\
\hline & & Added & Dropped & \\
\hline \multicolumn{5}{|l|}{ For whole sample } \\
\hline \multirow{2}{*}{\multicolumn{2}{|c|}{$\begin{array}{l}\text { Number of observations } \\
\text { Nearest neighhr matchino }\end{array}$}} & 691 & 691 & 691 \\
\hline & \\
\hline \multirow[t]{2}{*}{ ATT } & Coeff & 0.099 & 0.087 & -0.095 \\
\hline & z-value & 2.980 & 2.680 & -3.030 \\
\hline \multicolumn{5}{|l|}{ Regression results (b) } \\
\hline \multicolumn{5}{|l|}{ IV-LATE } \\
\hline \multirow[t]{2}{*}{ Treatment } & Coeff & 0.208 & 0.194 & -0.197 \\
\hline & t-value & 2.120 & 2.080 & -2.090 \\
\hline \multirow[t]{2}{*}{ Intercept } & Coeff & 0.575 & 0.463 & 0.493 \\
\hline & $\mathrm{t}$-value & 30.430 & 25.850 & 27.290 \\
\hline \multicolumn{5}{|l|}{ For control/treatment 1 villages } \\
\hline Number of observations & & 445 & 445 & 445 \\
\hline \multicolumn{5}{|l|}{ Nearest neighbor matching (a) } \\
\hline \multirow[t]{2}{*}{ ATT } & Coeff & 0.045 & 0.074 & -0.077 \\
\hline & z-value & 0.880 & 1.560 & -1.650 \\
\hline \multicolumn{5}{|l|}{ Regression results (b) } \\
\hline \multirow[t]{2}{*}{ Treatment } & Coeff & 0.187 & 0.189 & -0.198 \\
\hline & t-value & 1.260 & 1.320 & -1.400 \\
\hline \multirow[t]{2}{*}{ Intercept } & Coeff & 0.629 & 0.503 & 0.489 \\
\hline & t-value & 13.540 & 11.230 & 11.110 \\
\hline
\end{tabular}
(a) Matching based on village triplet code dummies.
(b) Village triplet code dummies included but not reported.
(c) overlap index of sales location between years, weighted by quantity - see text for details $\mathrm{t}$-values based on standard errors clustered by village triplet code.

We continue our investigation of crop marketing in Table 9. The unit of analysis is an individual sale transaction. We first examine whether farmers sell at a wholesale market or mandi. As we have discussed earlier, farmers may choose to sell at the mandi because it is the only way to obtain accurate price information, even though doing so raises transaction costs relative to farm-gate sales. If this is the case, the RML service may give farmers the confidence not to sell at the wholesale market, for instance, because they can better negotiate with a farm-gate buyer.

To investigate this possibility, we test whether treated farmers are less likely to sell at the mandi. Results, reported in the first column of Table 9, indicate that this is not the case: The intent-to-treat ATT, reported at the top of column 1 , raises the likelihood of selling at the mandi. In the rest of column 1 we examine whether the results are different when we use IV-LATE instead, or when we allow for heterogeneous effect by firm size and farmer age. Results are qualitatively similar. The magnitude of the effect, however, is small, 
TABLE 9. Other marketing characteristics, all transactions

\begin{tabular}{|c|c|c|c|c|c|}
\hline & $\begin{array}{c}\text { Sold in } \\
\text { wholesale } \\
\text { market }\end{array}$ & $\begin{array}{l}\text { if whole-sale } \\
\text { market, chosen } \\
\text { because closest }\end{array}$ & $\begin{array}{l}\text { Sold through a } \\
\text { commission } \\
\text { agent }\end{array}$ & $\begin{array}{l}\text { Sold to } \\
\text { trader }\end{array}$ & $\begin{array}{c}\text { Crop was } \\
\text { graded/sorted } \\
\text { before sale }\end{array}$ \\
\hline \multicolumn{6}{|l|}{ For whole sample } \\
\hline $\begin{array}{l}\text { Number of } \\
\text { observations }\end{array}$ & 1477 & 1352 & 1482 & 1470 & 1478 \\
\hline \multicolumn{6}{|c|}{ Nearest neighbor matching (a) } \\
\hline \multirow[t]{2}{*}{ ATT } & 0.030 & -0.078 & 0.006 & 0.046 & 0.033 \\
\hline & 2.540 & -3.220 & 0.230 & 1.740 & 2.260 \\
\hline \multicolumn{6}{|l|}{ Regression results $(b)$} \\
\hline \multirow[t]{2}{*}{ Treatment } & 0.063 & -0.131 & 0.539 & 0.084 & 0.055 \\
\hline & 1.750 & -0.940 & 0.844 & 1.050 & 1.120 \\
\hline \multirow{2}{*}{ Intercept } & 0.923 & 0.199 & 0.933 & 0.450 & 0.925 \\
\hline & 132.800 & 6.940 & 89.080 & 28.350 & 98.140 \\
\hline \multicolumn{6}{|c|}{ 2. Heterogeneous effects (c) } \\
\hline \multirow[t]{2}{*}{ Treatment } & 0.032 & -0.064 & 0.054 & 0.039 & -0.029 \\
\hline & 1.820 & -1.010 & 0.620 & 1.010 & -1.120 \\
\hline \multirow[t]{2}{*}{ Intercept } & 0.955 & 0.277 & 0.898 & 0.355 & 0.045 \\
\hline & 57.990 & 4.760 & 19.650 & 6.900 & 2.830 \\
\hline \multirow{2}{*}{$\begin{array}{l}\text { Dummy young Coeff } \\
\text { head of hh t-value }\end{array}$} & -0.013 & -0.091 & 0.049 & 0.140 & -0.024 \\
\hline & -1.080 & -2.100 & 0.690 & 2.950 & -1.180 \\
\hline \multirow{2}{*}{$\begin{array}{l}\text { Total crop area Coeff } \\
\text { cultivated t-value }\end{array}$} & -0.002 & -0.001 & -0.001 & 0.001 & -0.002 \\
\hline & -1.620 & -0.400 & -0.580 & 0.570 & -1.410 \\
\hline \multicolumn{6}{|c|}{ Interaction with treatment } \\
\hline Dummy young Coeff & 0.011 & 0.094 & -0.015 & -0.159 & 0.052 \\
\hline head of hh t-value & 0.590 & 0.460 & -0.120 & -2.330 & 1.950 \\
\hline \multirow{2}{*}{$\begin{array}{l}\text { Total crop area Coeff } \\
\text { cultivated t-value }\end{array}$} & 0.003 & 0.002 & -0.008 & -0.002 & 0.002 \\
\hline & 1.790 & 0.460 & -1.330 & -1.130 & 1.380 \\
\hline
\end{tabular}

(a) Matching based on village triplet code dummies.

(b) Village triplet code dummies included but not reported.

(c) Mean value substracted from those control variables interacted with treatment. $\mathrm{t}$-values based on standard errors clustered by village triplet code;

$\mathrm{t}$-values in bold significant at the $10 \%$ level or better.

probably because most farmers already sell at the mandi. When we differentiate the effect by crop, it is significant for pomegranates (point estimate 0.157 with $z$-value of 2.35) and-less so-for soya (point estimate 0.079 with z-value of $1.73)$; it is not significant for the other three crops. That pomegranates are most affected is hardly surprising given that pomegranates are the only crop with a sizable proportion of farm-gate sales at baseline. Thus, if anything, RML makes farmers more likely to sell at the mandi.

Among farmers who sell at the market, however, Table 9 has shown a change in crop destination. To verify this further, we asked farmers who sell at a particular wholesale market whether they do so because it is the closest market. We see from the second column of Table 9 that treated farmers are 
less likely to say they sell at a market because it is closest. Taken together, the evidence therefore suggests that treated farmers are more likely to sell farther away from home-either by switching from farm-gate to market sale or by switching to a more distant mandi.

To investigate this further, we test whether treated farmers are more likely to sell directly to a trader (typically at the farm-gate) or without the help of a commission agent. If RML improves price information, farmers may be less reluctant to sell to a trader, knowing they can insist on a price commensurate to the price at the nearest mandi. By a similar reasoning, they may rely less on commission agents who are contractually obliged to help farmers get the best price but to whom a fee must be paid. Table 9 shows this is not the case for commission agents - the ATT is not significantly different from 0 in any of the three methods we report. For selling to a trader, we find a weakly significant ATT, but significance disappears when we use IV-LATE or allow for heterogeneous effects. In the heterogeneous effect regression reported in the last panel of Table 9, we see that young farmers are more likely to report selling to a trader, but this relationship disappears with treatment, suggesting that young farmers learn not to sell to traders.

Taking columns 1 to 4 together, the evidence suggests that RML helped some farmers realize that they could obtain a higher price by going to a more distant mandi rather than selling at a closer market or at the farm-gate. It is possible that some farmers choose to sell locally because of uncertainty regarding the return from traveling to the more distant mandi. Providing information about the mandi price reduces the risk of traveling to the mandi, and the reduction in uncertainty may be what induced some farmers to incur the additional cost of traveling. In contrast, the evidence does not support the hypothesis that better informed farmers are emboldened to sell in local markets or at the farmgate because they can insist on receiving a price more in line with the regional wholesale price.

Finally, RML provides information on the price spread due to crop quality, that is, it shows prices by grade. Consequently, we expect treated farmers to pay more attention to quality, for instance, by grading or sorting their output into separate categories to obtain a better price on the top quality. This is what we find (see the last column of Table 9) for the ATT where the effect is statistically significant. The magnitude of the effect, however, is small: treatment raises the proportion of farmers grading or sorting their output by 3 percentage points. The effect also disappears in the IV-LATE regression; it resurfaces in the heterogeneous effect regression, but only when interacted with farmer age-that is, young farmers are slightly more likely to grade or sort their output as a consequence of treatment.

\section{Weather Information}

RML provides weather forecasts that are spatially disaggregated-and hence presumably more accurate than those publicized on the radio. Do RML 
forecasts help farmers improve yields, for instance, because farmers can take better anticipative action?

We investigate this question in Table A.3 in the supplemental appendix. Farmers were asked whether or not they incurred unusually high rainfall events, such as a storm or heaving downpour. Some 58 percent said they did. The likelihood of reporting a storm is correlated with treatment in the IV and heterogeneous effect regressions: treated farmers are more likely to report incurring a storm. Since we have no reason to believe that the weather is correlated with treatment, this is most likely due to response bias: farmers who receive regular weather information become more aware of unusual rainfall events, and are more likely to report them to enumerators.

We test whether treated farmers were able to reduce output loss or increase output following a storm. We find no evidence that this is the case. We also find little evidence of beneficial heterogeneous effects: young farmers report more output loss at harvest following a storm, not less.

\section{Agricultural Technology and Practices}

In addition to price and weather information, RML provides crop advisory messages relaying information on crop varieties, pesticide use, and cultivation practices. This information may be particularly valuable for sample farmers because some of our target crops are relatively new to them.

In Table 10 we examine whether farmers changed the variety of the target crop that they grow. Some 31 percent of respondents stated they did change variety between the two survey years, but this proportion is the same irrespective of treatment. Of those who changed variety, 65 percent stated they did so to improve profitability. Again we find no statistical relationship with treatment. Farmers who stated they changed crops to improve profitability were asked whether they did so because of RML. Here we find a statistically positive treatment effect: depending on the estimation method, treated farmers are 1420 percent more likely to list RML as inspiration for the change. This is reassuring, but not necessarily conclusive given that treatment is found to have no effect on the propensity to change variety or on the reason for changing variety.

In the last two columns of Table 10 we turn to cultivation practices. In 2010 farmers were asked whether they changed anything about their cultivation practices since the previous year; 22 percent of respondents stated they did so. We find no evidence that treated farmers were more likely to change cultivation practices.

Those who did change were asked what made them change practices. Of those farmers who report a change, a large proportion mentions RML as the reason for the change. The effect is statistically significant and large in magnitude-a 20-41 percent higher likelihood of listing RML, depending on the estimator. As for crop variety, this evidence is reassuring but not conclusive 
TABLE 10. Crop varieties grown and cultivation practices

\begin{tabular}{|c|c|c|c|c|c|c|}
\hline \multicolumn{2}{|l|}{$\begin{array}{l}\text { For whole } \\
\text { sample }\end{array}$} & $\begin{array}{l}\text { Change of crop } \\
\text { variety since } \\
\text { last year }\end{array}$ & $\begin{array}{l}\text { If yes, } \\
\text { reason is } \\
\text { profita- } \\
\text { bility }\end{array}$ & $\begin{array}{c}\text { If } \\
\text { profitability, } \\
\text { because of RML }\end{array}$ & $\begin{array}{l}\text { Change in } \\
\text { cultivation } \\
\text { practices last year }\end{array}$ & $\begin{array}{l}\text { If change, } \\
\text { because of } \\
\text { RML }\end{array}$ \\
\hline \multicolumn{2}{|l|}{$\begin{array}{l}\text { Number of } \\
\text { observations }\end{array}$} & 895 & 240 & 156 & 911 & 203 \\
\hline \multicolumn{7}{|c|}{ Nearest neighbor matching (a) } \\
\hline \multirow[t]{2}{*}{ ATT } & Coeff & 0.029 & 0.020 & 0.155 & -0.027 & 0.211 \\
\hline & z-value & 1.100 & 0.460 & 2.830 & -1.110 & 3.990 \\
\hline \multicolumn{7}{|c|}{ Regression results (b) } \\
\hline \multirow[t]{2}{*}{ Treatment } & Coeff & 0.043 & 0.006 & 0.200 & -0.045 & 0.410 \\
\hline & $\mathrm{t}$-value & 0.970 & 0.090 & 2.060 & -1.240 & 5.170 \\
\hline \multirow[t]{2}{*}{ Intercept } & Coeff & 0.525 & 0.374 & -0.033 & 0.476 & -0.016 \\
\hline & $\mathrm{t}$-value & 59.350 & 30.950 & -2.060 & 65.780 & -0.950 \\
\hline \multicolumn{7}{|c|}{ 2. Heterogeneous effects (c) } \\
\hline \multirow[t]{2}{*}{ Treatment } & Coeff & 0.021 & -0.003 & 0.140 & -0.025 & 0.199 \\
\hline & $\mathrm{t}$-value & 0.910 & -0.080 & 2.220 & -1.270 & 3.580 \\
\hline \multirow[t]{2}{*}{ Intercept } & Coeff & 0.518 & 0.408 & -0.112 & 0.432 & -0.051 \\
\hline & $\mathrm{t}$-value & 17.210 & 9.280 & -5.680 & 14.940 & -1.270 \\
\hline \multirow{2}{*}{$\begin{array}{c}\text { Dummy young } \\
\text { head of hh }\end{array}$} & Coeff & -0.001 & -0.079 & 0.103 & 0.042 & 0.036 \\
\hline & t-value & -0.030 & -1.280 & 2.350 & 0.890 & 0.850 \\
\hline \multirow{2}{*}{$\begin{array}{c}\text { Total crop area } \\
\text { cultivated }\end{array}$} & Coeff & 0.001 & 0.002 & 0.001 & 0.001 & 0.000 \\
\hline & $\mathrm{t}$-value & 0.770 & 1.640 & 0.980 & 1.310 & -0.030 \\
\hline \multicolumn{7}{|c|}{ Interaction with treatment } \\
\hline \multirow{2}{*}{$\begin{array}{l}\text { Dummy young } \\
\text { head of hh }\end{array}$} & Coeff & -0.091 & 0.053 & -0.001 & -0.009 & 0.033 \\
\hline & $\mathrm{t}$-value & -1.760 & 0.680 & -0.010 & -0.150 & 0.220 \\
\hline \multirow{2}{*}{$\begin{array}{c}\text { Total crop area } \\
\text { cultivated }\end{array}$} & Coeff & -0.002 & 0.000 & 0.000 & -0.001 & 0.001 \\
\hline & $\mathrm{t}$-value & -1.240 & -0.120 & 0.100 & -0.910 & 0.210 \\
\hline
\end{tabular}

(a) Matching based on village triplet code dummies.

(b) Village triplet code dummies included but not reported.

(c) Mean value substracted from those control variables interacted with treatment.

$\mathrm{t}$-values based on standard errors clustered by village triplet code;

$\mathrm{t}$-values in bold significant at the $10 \%$ level or better.

given that treatment has no noticeable effect on changing crop practices themselves.

\section{CONCLUSION}

We have reported the results of a randomized controlled trial of the impact of an SMS-based agricultural information service in Maharashtra. This information service, called Reuters Market Light (RML), sends SMS to farmers with information on prices, weather forecasts, crop advice, and news items. The price information is expected to improve farmers' ability to negotiate with 
buyers and to enable them to arbitrage better across sales outlets. Weather information should help farmers reduce crop losses due to storms. Crop advisory information should induce farmers to adopt new crop varieties and improve cultivation practices.

The trial was conducted in collaboration with Thomson-Reuters, the provider of RML. The experiment involved 933 farmers in 100 villages of central Maharashtra. Treatment was randomized across villages and, in some cases, across farmers as well. Participating farmers were surveyed twice in face-to-face interviews. We also conducted a follow-up telephone survey to gather information on reasons for non-compliance. Randomization appears to have worked well in the sense that the control and treatment samples are balanced on most relevant variables. Although contamination is limited, non-compliance is common, which is why we reported intent-to-treat estimates throughout. We also reported instrumental variable (IV) estimates in which selection into treatment is used to instrument RML usage.

We find no statistically significant average treatment effect on the price received by farmers, crop losses resulting from rainstorms, or the likelihood of changing crop varieties and cultivation practices. Treated farmers appear to make use of the RML service and they associate RML information with a number of decisions they have made. But, based on the available evidence, on average they would have obtained a similar price or revenue, with or without RML.

Although disappointing, our results are in line with the RML take-up rate in the study districts. After a rapid expansion following the introduction of the service in 2007-09, take-up shows a relative stagnation in 2009-10, suggesting a possible loss of interest. We cannot, however, rule out that supply-side factors played a role. We also suspect that some farmers do not know how to renew the service. ${ }^{13}$

Although the absence of positive effect on price may surprise and disappoint, we find evidence of an RML information effect on where farmers sell their crop: they are less likely to sell at the farm-gate-especially young farmers-and more likely to sell at a different, more distant wholesale market. These results contradict the idea that RML information enables farmers to negotiate better prices with itinerant traders, but are consistent with using RML information to arbitrage across sales outlets. Why arbitrage does not translate into higher prices is unclear, but some possible explanations arise from the data. First, few farmers sold at the farm-gate at baseline-except for pomegranates-thereby limiting the number of farmers who could realize that selling at the market was more beneficial than selling at the farm-gate, as a few did. Second, before treatment crop sales were concentrated on a single wholesale market in each district. Spatial concentration probably limits the range of

13. The provider has indeed encountered difficulties in setting up a reliable system for enabling clients to easily and reliably make repeat purchases of the RML service. 
alternative market destinations nearby-and thus opportunities for arbitraging by farmers.

We find little evidence of other RML effects. If RML information helps farmers improve crop quality, we should observe treated farmers changing agricultural practices, especially for crop varieties and grading. We do not, except for grading but the magnitude of the effect is small. We also find no significant effect on transaction costs, revenues, and value-added.

Taken together, the evidence is consistent and compelling. Surveyed farmers sell almost exclusively to a wholesale agricultural market nearby. If traders have a comparative advantage in transport, for example because farmers do not know anyone they can trust in other markets (Gabre-Madhin 2001), trader arbitrage across markets should ensure that farmers cannot fetch a more remunerative price by selling elsewhere. Hence it is optimal for farmers to sell to the nearest market. Similarly, if farmers fear being cheated when they sell at the farm-gate, it is optimal for them not to do so. Given this, it is perhaps not so surprising that better price information did not translate into higher farmer prices. $^{14}$

If the above interpretation is correct, it has a number of implications for the external validity of our findings. Price information could help if spatial arbitrage across agricultural markets does not hold, for example because markets are disorganized, segmented, or too thin to attract a steady flow of buyers-or because producers have a comparative advantage in transport, as in Jensen (2007). Even in such a case, however, price information is likely to be used first by traders, as documented by Aker (2008). Price information could also help farmers who sell at the farm-gate, such as the coffee growers studied by Fafchamps and Hill (2008). A stronger effect on crop quality may be obtained if price information is detailed by variety and grade and if farmers are provided with complementary information on how to produce high-price varieties and grades. These suggestions should help steer policy intervention toward regions and markets where the effect of price information may be beneficial, and avoid wasting resources on markets where it is unlikely to matter.

\section{REFERENCES}

Abadie, A., D. Drukker, J. L. Herr, and G. W. Imbens. 2004. "Implementing Matching Estimators for Average Treatment Effects in Stata.” Stata Journal 4 (3): 290-311.

Aker, J.C. 2008. Does Digital Divide or Provide? The Impact of Mobile phones on Grain Markets in Niger. Berkeley: University of California Press.

14. Nothing in this argument relies on buyer competition within each market: Even if buyers act in a monopsonistic fashion, as documented by Banerji and Meenakski (2004) for Delhi wheat markets, giving farmers information about market prices would not improve farmer prices-unless buyers price discriminate across markets and spatial arbitrage does not hold. 
Aker, J. C., and M. Fafchamps. 2011. Mobile Phones and Farmers' Welfare in Niger. Berkeley: University of California Press.

Banerji, A., and J. V. Meenakski. 2004. "Buyer Collusion and Efficiency of Government Intervention in Wheat Markets in Northern India: An Asymmetrical Structural Auction Analysis." American Journal of Agricultural Economics 86 (1): 236-253.

Bruhn, M., and D. McKenzie. 2009. "In Pursuit of Balance: Randomization in Practice in Development Field Experiments." American Economic Journal: Applied Economics 1 (4): 200-232.

Deaton, A. 2009. Instruments of Development: Randomization in the Tropics, and the Search for the Elusive Keys to Economic Development. NBER Working Paper \#14690.

Fafchamps, M., and R. V. Hill. 2008. "Price Transmission and Trader Entry in Domestic Commodity Markets." Economic Development and Cultural Change 56 (4): 729-766.

Gabre-Madhin, E. 2001. "The Role of Intermediaries in Enhancing Market Efficiency in the Ethiopian Grain Market.” Agricultural Economics 25 (2-3): 311-320.

Goyal, A. 2010. "Information, Direct Access to Farmers, and Rural Market Performance in Central India." American Economic Journal: Applied Economics 2 (July): 22-45.

Jensen, R. 2007. “The Digital Provide: Information (Technology), Market Performance, and Welfare in the South Indian Fisheries Sector.” Quarterly Journal of Economics 127 (3): 879-924.

Mattoo, A., D. Mishra, and A. Narain. 2007. From Competition at Home to Competing Abroad. Washington, DC: World Bank.

Minten, B., A. Vandeplas, and J. Swinnen. 2012. "Regulations, Brokers, and Interlinkages: The Institutional Organization of Wholesale Markets in India." Journal of Development Studies, forthcoming.

Mittal, S., S. Gandhi, and G. Tripathi. 2010. Socio-Economic Impact of Mobile Phone on Indian Agriculture. ICRIER Working Paper no. 246. New Delhi: International Council for Research on International Economic Relations.

Staatz, J.M., A.M. Kizito, M.T. Weber, and N.N. Dembélé 2011. Evaluating the Impact on Market Performance of Investments in Market Information Systems: Methodological Challenges. MSU Staff Paper 2011-08. East Lansing: Department of Agricultural, Food and Resource Economics, Michigan State University.

Wooldridge, J. M. 2002. Econometric Analysis of Cross Section and Panel Data. Cambridge, MA: MIT Press.

World Bank. 2010. India Economic Update, June 232010. 